\title{
IDENTIFICATION AND DIFFERENTIATION OF THE ASIAN ELEPHANT IVORY BY USING SCHREGER LINES
}

Dinesh Kumar Jha, Nirajan Thapa Kshetry, Basanta Raj Pokharel, Sudhir K. Lal and Raju Panday

Journal of Institute of Science and Technology

Volume 22, Issue 1, July 2017

ISSN: 2469-9062 (print), 2467-9240 (e)

Editors:

Prof. Dr. Kumar Sapkota

Prof. Dr. Armila Rajbhandari

Assoc. Prof. Dr. Gopi Chandra Kaphle

JIST, 22 (1): 99-103 (2017)

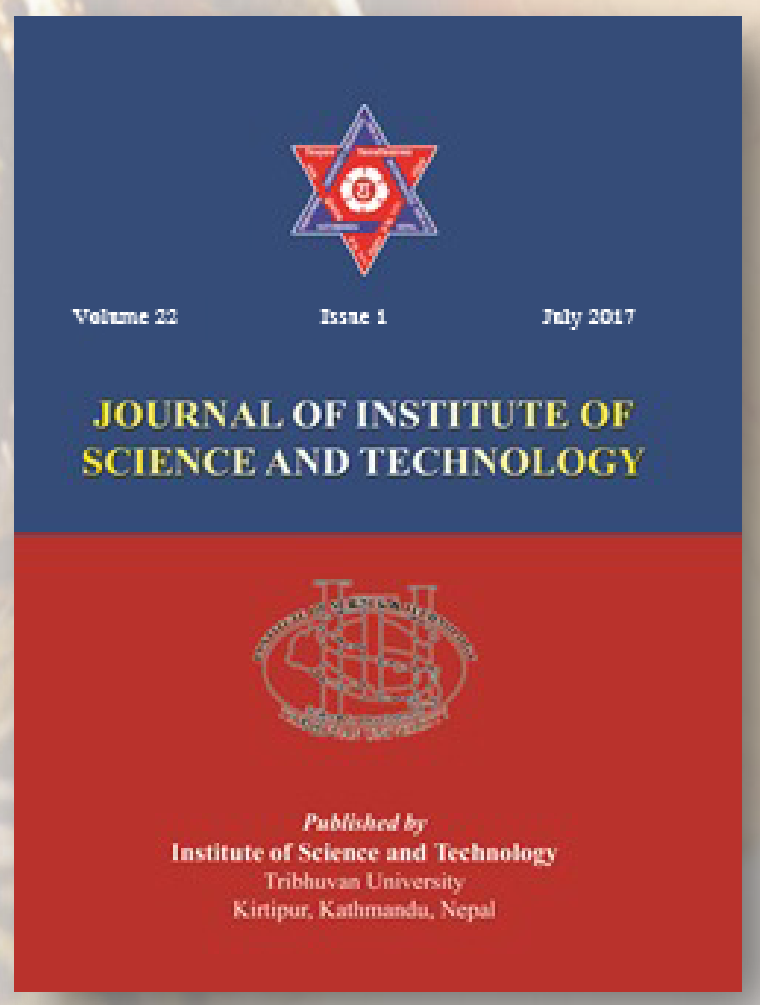

Published by:

Institute of Science and Technology

Tribhuvan University

Kirtipur, Kathmandu, Nepal 


\title{
IDENTIFICATION AND DIFFERENTIATION OF THE ASIAN ELEPHANT IVORY BY USING SCHREGER LINES
}

\author{
Dinesh Kumar Jha ${ }^{1, *}$, Nirajan Thapa Kshetry ${ }^{1}$, Basanta Raj Pokharel ${ }^{1}$, \\ Sudhir K. Lal ${ }^{2}$ and Raju Panday ${ }^{1}$ \\ ${ }^{I}$ National Forensic Science Laboratory, Khumaltar, Lalitpur, Nepal \\ ${ }^{2}$ Butwal Multiple Campus, Tribhuvan University, Butwal, Nepal \\ *Corresponding E-mail: dineshforensic@gmail.com
}

\begin{abstract}
Elephant ivory is one of the highly priced, illegally traded wildlife trophies and its identification has always been a challenging task. A total of 21 Asian elephant tusks stored at the office of the Chitwan National Park, Kasara, Nepal were morphometrically studied with an aim to typify elephant ivory by using Schreger lines. The ivory samples were cleaned, their Schreger lines were photographed and their angles were measured by using a protractor. A total of 120 Schreger angles data from both outer and inner areas were obtained resulting both concave and convex appearance. The observed maximum and minimum Schreger angles values were $125^{\circ}$ and $50^{\circ}$ respectively. The mean Schreger angle was found to be $95.60^{\circ}( \pm 14.23)$. The Schreger lines were present in all studied samples. Thus, it is concluded that the presence of Schreger line is the identifying feature of an elephant tusk.
\end{abstract}

Keywords: Elephas maximus, Tusk, Morphometry, Schreger lines, Wildlife forensics.

\section{INTRODUCTION}

The illegal trade of body parts and products is a serious threat to the survival of the many wildlife species. The ivory and artifacts made from it has always been found in the illegal trade and elephant ivory trade has special significance, due to the fact that its import and export are illegal. Elephant ivory is highly valued and is derived from two elephantine species that currently survive; the Asian elephant (Elephas maximus) and the African elephant (Loxodonta africana) (Bracco et al., 2013). These species are included in Appendix I/II of the CITES. The Asian elephant (Elephas maximus), inhabiting primarily India, Nepal and Sri Lanka is also included in the Nepal government's National Parks and Wildlife Conservation Act 1973 (BS 2029). As per provision in the Act, any person found guilty of possessing, selling or buying elephant ivory is subject to a fine of NRs. 50,000 to 100,000 (NRs $5,00,000$ to $10,00,000$ is proposed but still not endorsed by the government) (1USD 105NRs) or 5-15 years of imprisonment or both. Conservation of the Asian elephant is of great concern as large numbers of elephants are being poached for ivory every year (Menon \& Kumar, 1998).
Identification and species determination (Asian or African) of seized ivory and its products are always challenging tasks and they are based on the physical, chemical and genetic characteristics of these materials. Ivory microstructure analyses provide the necessary information to determine the origin of the artifacts made from the ivory. The Schreger lines, in proboscidean dentine, described by the German anatomist Bernhard Gottlob Schreger in 1800 (Obermayer, 1881) is recognized as an important tool for identification of elephant ivory materials (Espinoza \& Mann, 1991; Palombo \& Villa, 2001; Trapani \& Fisher, 2003; Wasser et al., 2007; Bracco et al., 2013).

Schreger pattern, also referred to as 'cross-hatchings', 'engine turnings', or 'stacked chevrons' (Espinoza \& Mann, 1991), is the shadow phenomenon created primarily by the differential reflection of light caused by sinusoidal changes in the direction of travel of the dentinal tubules, and consequent changes in the orientation of the microstructure of the surrounding dentine matrix (Miles \& White, 1960; Locke, 2008; Edwards et al., 2012). They are apparent in crosssection of elephant tusk (Palombo \& Villa, 2001). The Schreger pattern can have two expression areas. The easily visible lines closest to the cementum are the outer Schreger lines. The faint but tightly packed 
lines found around the tusk nerve pulp cavities are the inner Schreger lines. The intersections of Schreger lines form angles (Espinoza \& Mann, 1991) which are produced when dentinal tubules, produced by odontoblasts move towards the tusk axis during dentine deposition (Miles, 1967). The Schreger angles appear in concave as well as convex forms; the concave angles have slightly concave sides and open medially (inner) and the convex angles have somewhat convex sides open towards the periphery (outer) of the tusk (Espinoza \& Mann, 1991; Singh et al., 2006).

Fast, easy and accurate analysis of Schreger pattern for the characterization of the ivory is of great importance for the forensic purposes. The Asian elephant ivory is more valuable than that of African elephant (Menon \& Kumar, 1998) and thus species determination becomes important. In this paper, the technique of morphometric analysis of ivory of the Asian Elephant is carried out using Schreger lines, this will help the concerned people of enforcement agencies in getting rapid and reliable identification of the seized materials.

\section{MATERIALS AND METHODS}

A total of 21well labeled Asian elephants ivory stored in office of the Chitwan National Park, Kasara, Nepal were included in this study. The Schreger angle measurement technique used in this study is partly similar to guidelines provided by USFWS (United States Fish and Wildlife Service) and CITES (Convention on International Trade in Endangered Species of Wild Fauna and Flora) for identification of the ivory (Espinoza \& Mann, 1991). The Schreger patterns from elephant ivory cross sections were captured by using digital camera (SONY, Model: DSCW690). Later on, two to seven Schreger angles were marked in each ivory sample depending on its clarity (Figure 1). Both outer and inner as well as concave and convex Schreger angles were used in the study. Prints were developed and measurements of the angles were obtained by using a Protractor. Finally, data for each individual tusk consisting of measurements taken at various radial distances (Abelova, 2008) were analyzed in Microsoft Excel program.

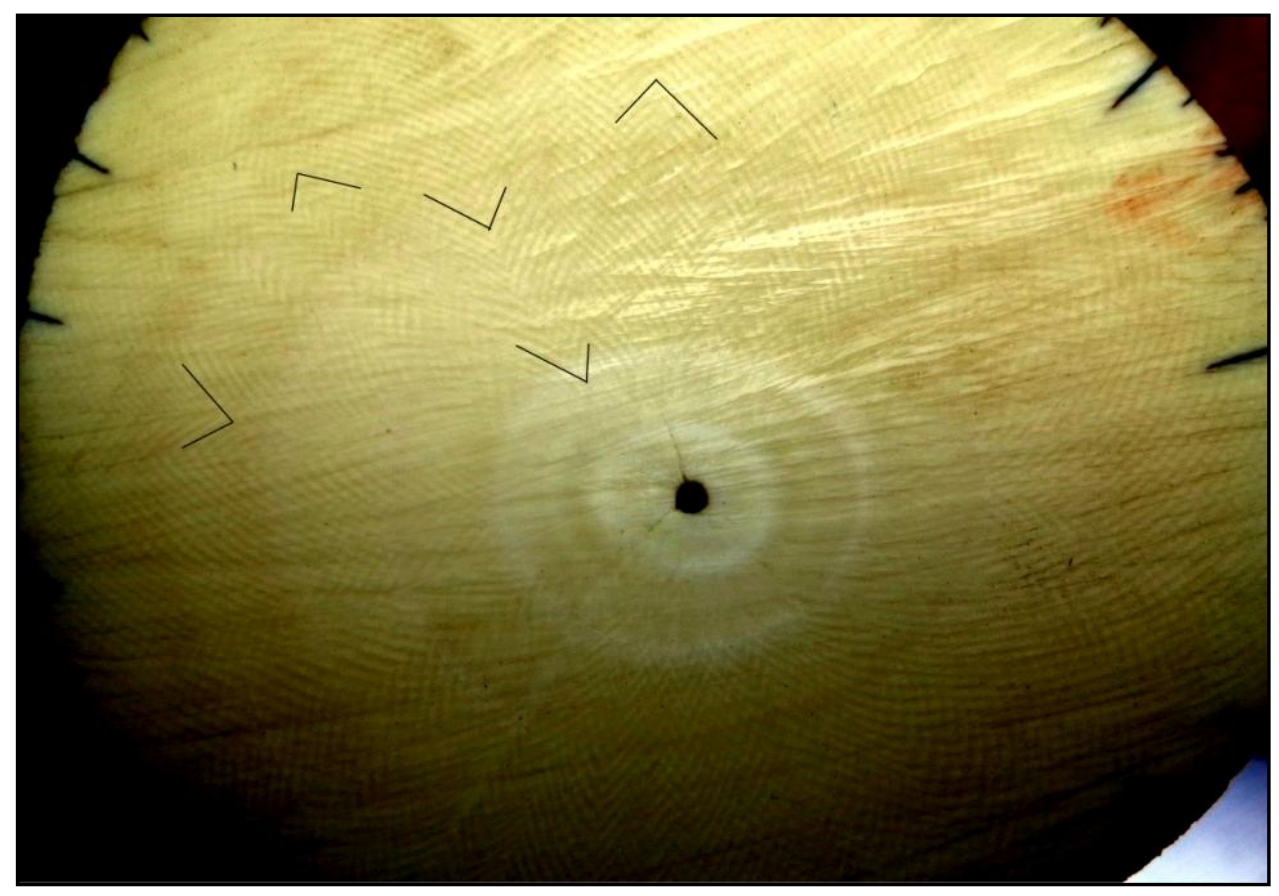

Fig.1. Schreger angles and their demarcation in ivory of the Asian Elephant.

\section{RESULTS AND DISCUSSION}

A total of $120(\mathrm{n})$ angles were measured from $21(\mathrm{~N})$ Asian Elephant ivory. Maximum values of $125^{\circ}$ and the minimal values of $50^{\circ}$ were found for outer Schreger angles. Details of the measurements are provided in figure 2. Singh et al. (2006) observed the Schreger angle in the range of $30^{\circ}$ to $153^{\circ}$ in the Asian Elephant and $32^{\circ}$ to $145^{\circ}$ in African Elephant, which is slightly greater as compared to result of the present study. 


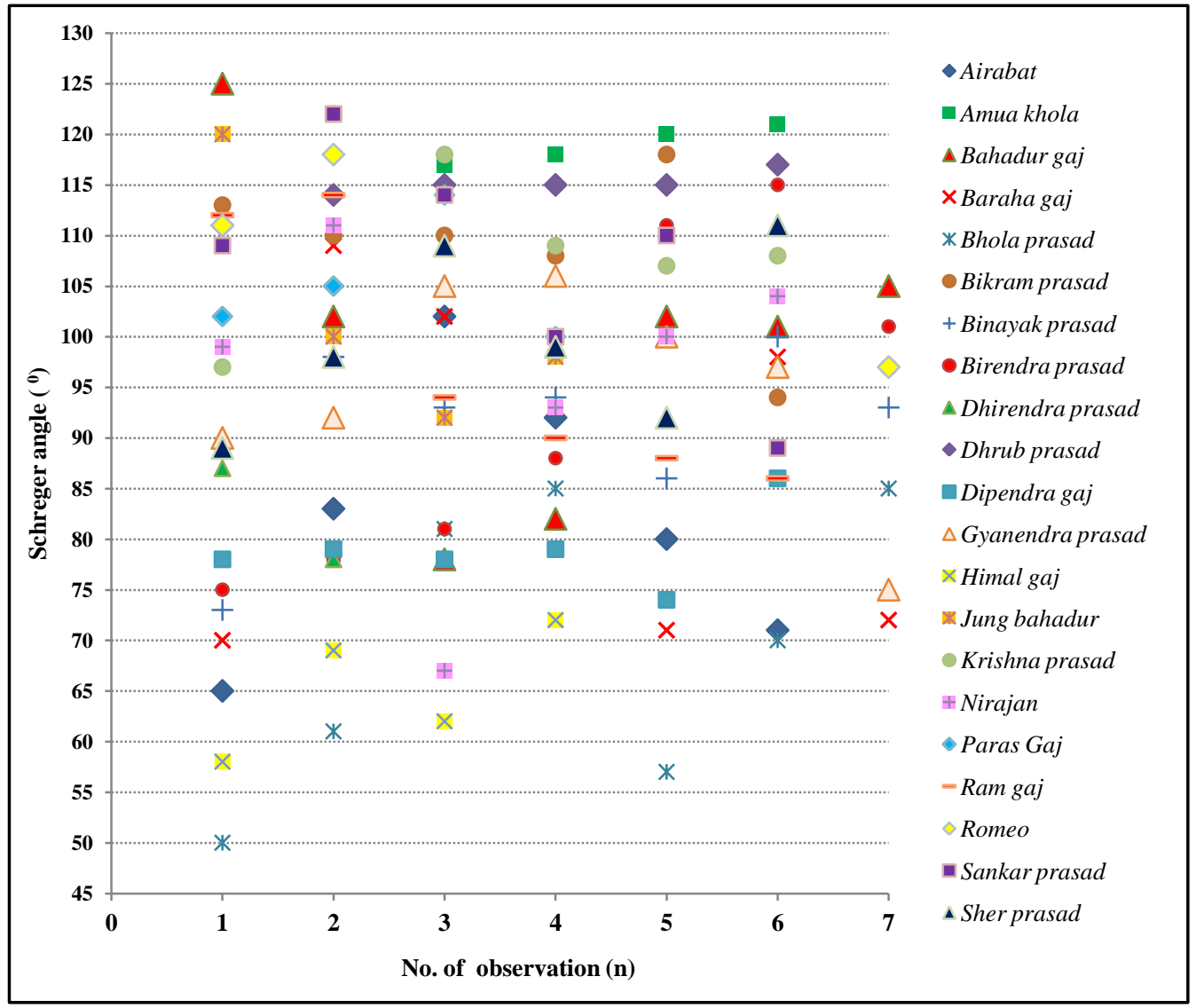

Fig. 2. Schreger angles $(n=120)$ distribution in the ivory samples $(N=21)$.

According to Espinoza and Mann (1991, 1993), the 'outer' Schreger angles can reach approximately $125^{\circ}$. In this study, among 120 Schreger angles measured, only $3 \%$ angles measured were greater than $120^{\circ}$. The highest frequency of angles measured $(22.5 \%)$ were in the range of $90^{\circ}-100^{\circ}$. Almost two-third i.e. $65 \%$ of the measurements was greater than $90^{\circ}$ (Figure 3.). There are several different findings among the results of Trapani and Fisher (2003), Singh et al. (2006), and the present study which might be because of the angle's measurements taken along different positions in the tusk. A wide range of Schreger angle observed in this study might be because of the fact that they were measured on samples taken from various unknown positions along the proximo-distal ivory axis. The Schreger angles depend on both the location of the sample from within the transverse ivory section, and also on their location along the proximo-distal ivory axis (Abelova, 2008). Schreger angles become smaller towards the tip of the ivory (Abelova, 2008).

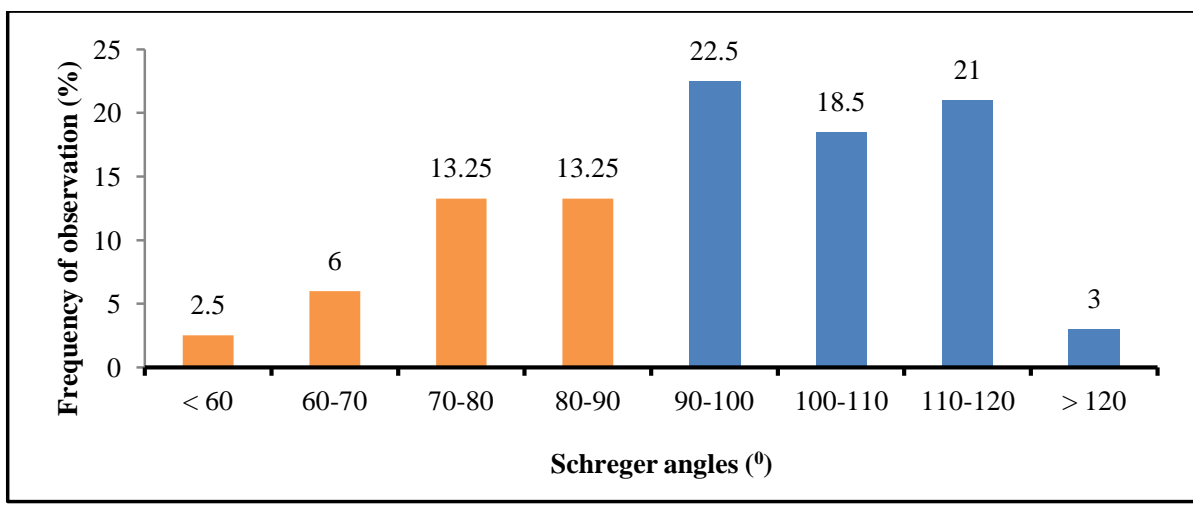

Fig. 3. Schreger angles and their frequency of observation $(n=120)$. 
The average Schreger angle calculated for each ivory ranged from $65.25^{\circ}$ to $117.83^{\circ}$ and mean Schreger angle in this study was found to be $95.60^{\circ}$ $( \pm 14.23)$. The mean Schreger angle observed by Singh et al. (2006) was $91.10^{\circ}( \pm 0.70)$. Almost
$62 \%(\mathrm{~N}=13)$ of the ivory had a average Schreger angle from $90^{\circ}$ to $110^{\circ}, 14 \%(\mathrm{~N}=3)$ had average Schreger angle from $110^{\circ}$ to $120^{\circ}$ and remaining $24 \%(\mathrm{~N}=5)$ had below $90^{\circ}$; whereas no sample had a average Schreger angle above $120^{\circ}$ (Figure 4).

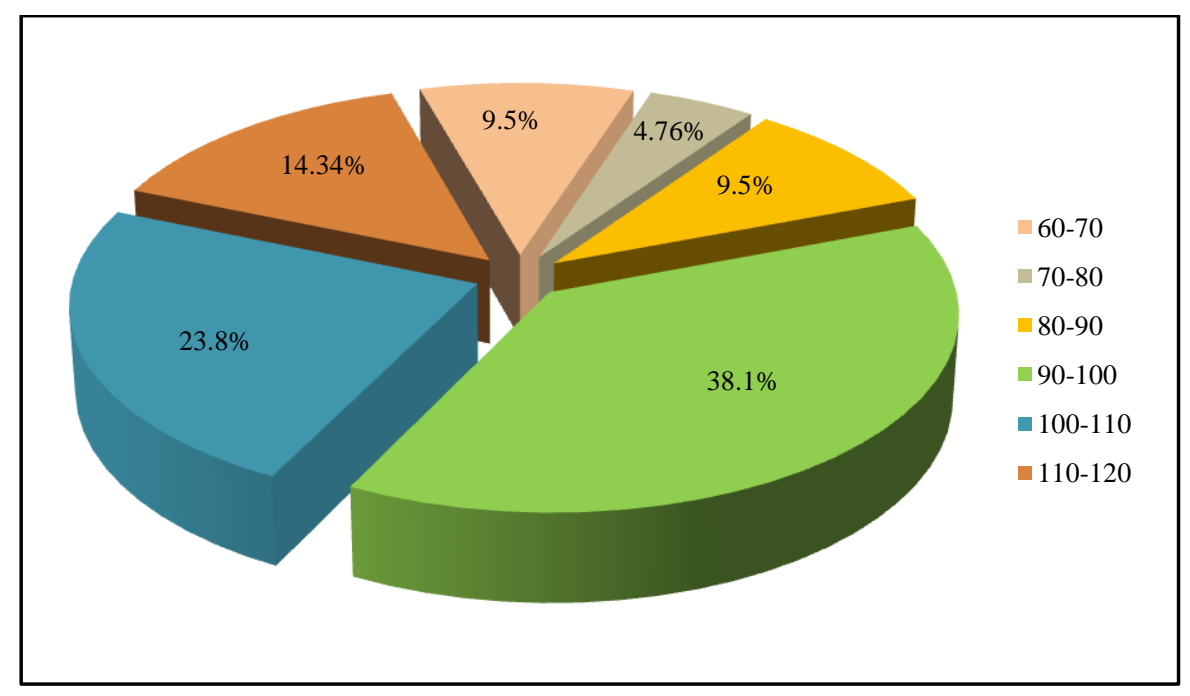

Fig. 4. Average Schreger angles (degrees) and percentage of tusks.

\section{CONCLUSION}

The visible and microscopic ability to identify tusks and fragments of different proboscides can be extremely helpful regarding the probable identification of elephant species without the use of diagnostic molars, skull or postcranial skeleton (Abelova, 2008). Singh et al. (2006) found that the morphometric measurement of the Schreger pattern and isotope analysis were among the useful techniques to distinguish African and Asian
Elephant ivory. Schreger lines and their unique patterns of intersecting arcs forming angles were present in all of the studied samples. Thus this characteristic feature of elephant ivory can be reliably applied in suspected ivory sample identification (Figure 5). Schreger pattern details observed in the present study requires more comparable data from both Asian and African elephants to ascertain its potential for the discrimination of the species.

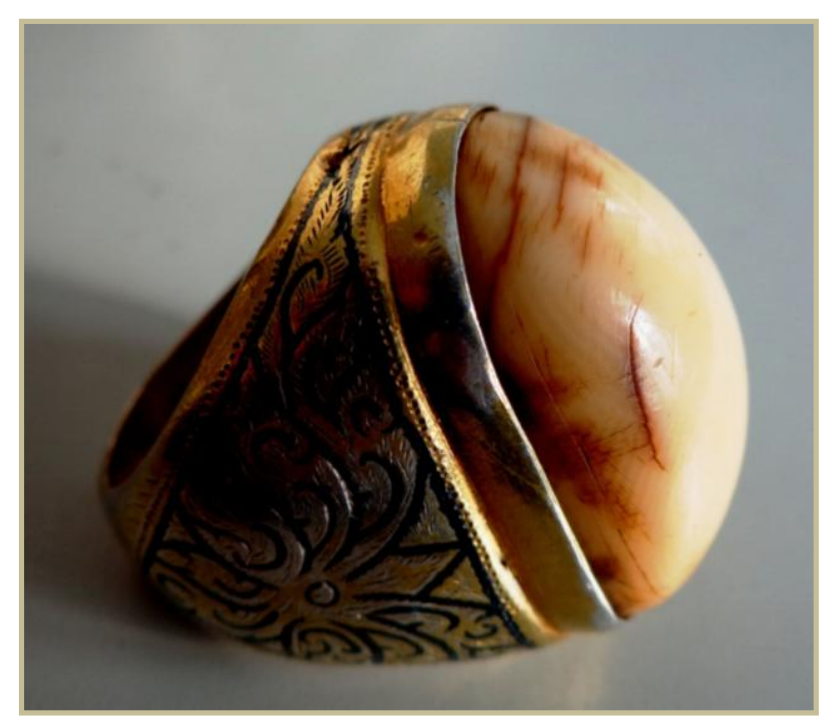

Fig. 5. Presence of schreger lines in a suspected ivory sample. 


\section{ACKNOWLEDGEMENT}

The authors are grateful to the Ministry of Science and Technology, Ministry of Forest and Soil Conservation, Department of National Parks and Wildlife Conservation and Department of Forest for crucial consent to carry out this work. We are thankful to the Mr. Jiwan Pd. Rijal, Director, National Forensic Science Laboratory, Nepal for his support in this research work. The authors would also like to thank the office of the Chitwan National Park, Chitwan for providing the ivory samples for the study.

\section{REFERENCES}

Abelova, M. (2008). Schreger pattern angles of Mammuthus primigenius tusk: analytical approach and utility. Bulletin of Geosciences, 83 (2): 225-232.

Bracco, S.; Brajkovic, A.; Comotti, A. and Rolandi, V. (2013). Characterization of Elephant and mammoth ivory by solid state NMR. Reriodice di mineralogia, 82: 239-250.

Edwards, H. G. M. and Vandenabeele, P. (2012). Analytical Archaeometry. RSC publishing, United Kingdom.

Espinoza, E. O. and Mann, M. J. (1991). Identification guide for ivory and ivory substitutes. World Wildlife Fund and The Conservation Foundation. Baltimore, MD.

Espinoza, E. O., and Mann, M. J. (1993). The History and Significance of the Schreger Pattern in Proboscidean Ivory Characterization. Journal of the American Institute for Conservation, 32 (3): 241-248.

Locke, M. (2008). Structure of ivory. Journal of Morphology, 269 (4): 423-450.

Menon, V. and Kumar, A. (1998). Signed and Sealed - The Fate of the Asian elephant. Report, Asian Elephant Research and Conservation Centre, Wildlife Protection Society of India. New Delhi.
Miles, A. E. W. and Poole, D. F. G. (1967). The history and general organization of dentitions, in: AEW Miles, (ed.), Structural and Chemical Organization of Teeth, Vol. 1, Academic Press, New York and London.

Miles, A. E. W. and White, J. W. (1960). Ivory. In: Proceedings of the Royal Society of Medicine. pp. 775-80.

Obermayer, F. (1881). Beitrag zur kenntnis des zahnbeines vom elefanten, nilpferd, walross und narwal.Verlag des Vereines der Wiener Handels-Akademie: 102-113.

Palombo, M. R. and Villa, P. (2001). Schreger lines as support in the Elephantinae identification. In G Cavarretta, P Gioia, V Mussi, and MR Palombo(eds) The World of Elephants. Proceedings of the 1st International Congress, Consiglio Nazionale delle Ricerche, Rome, Italy. pp. 656-660.

Singh, R. R.; Goyal, S. P.; Khanna, P. P.; Mukherjee, P. K. and Sukumar, R. (2006). Using morphometric and analytical techniques to characterize Elephant ivory. Forensic Science International, 162: 144-151.

Trapani, J. and Fisher, D. C. (2003). Discriminating proboscidean taxa using features of the Schreger pattern in tusk dentin. Journal of Archaeological Science, 30: 429-438.

Wasser, S. K.; Mailand, C.; Booth, R.; Mutayoba, B.; Kisamo, E.; Clark, B. et al. (2007). Using ivory to track the origin of the largest ivory seizure since 1989 trade ban. In: Proceedings of the National Academy of Sciences of the United States of America. pp.4228-4233. 